\title{
Géza Alföldy, Die epigraphische Kultur der Römer. Studien zu ihrer Bedeutung, Entwicklung und Erforschung, hrsg. von Angelos Chaniotis und Christian Witschel (Heidelberger Althistorische Beiträge und Epigraphische Studien - 50), Franz Steiner Verlag, Stuttgart 2018, 588 pp. + 185 b/w ill.; ISBN 978-3-515-12236-8
}

Géza Alföldy and his achievements are unquestionably known to every scholar of the history of imperial Rome. His numerous books and articles on various aspects of the social and political history of Rome under the rule of the emperors passed into the canon of the subject literature long ago. Alföldy's many studies were published in dozens of different journals, and as a result, gaining access to them has sometimes been difficult. This re-edition of the scholar's works therefore makes them much easier to find. The majority of Alföldy's articles were collected in several volumes in his lifetime, and re-edition generally also involved revision or adjustments to the views and conclusions expressed in the original edition, supplements to bibliographies, and presentation of the current state of discussion on the subjects and problems analysed in the various texts. The most recent such collection, prepared by Alföldy's long-time colleagues and collaborators Angelos Chaniotis and Christian Witschel, came out in 2018. Although this volume was published a number of years after his death, and it was the editors who determined its final shape, the author himself prepared a large section of the articles for re-edition, as well as writing the introduction ("Einführung: Zur Geschichte der epigraphischen Forschung," pp. 19-31).

The book contains 24 texts, published over a period of many years, concerning Latin epigraphy, its past, current state and future, as well as the importance of epigraphical sources in research on social history and the question of the use of inscriptions as a medium of imperial propaganda. Most of these articles are in German, two in English, one in French and one in some six languages (Latin, German, Italian, English, French and Spanish). The preponderance of texts in German might have a negative effect on their impact, as practice shows that many Anglophone scholars do not cite articles published in this language (fortunately, the original versions of some of these texts were published in a different language).

The book has two parts. The first, "Die epigraphische Kultur der Römer" (pp. 33390), comprises 17 articles. Some of these concern the use of epigraphical sources as a medium for the emperors' propaganda. This took place particularly in Rome itself, shaping the ruler's image as the most important figure in political and social life. This objective was served not only by the public and sacred buildings constructed by the 
emperors, but also the inscriptions placed on them and the new lettering style, size, and even techniques employed from Augustus' time onwards ("Augustus und die Inschriften: Tradition und Innovation. Die Geburt der imperialen Epigraphik," pp. 73-102; "Die Repräsentation der kaiserlichen Macht in den Inschriften Roms und des Imperium Romanum," pp. 103-116; "Der Glanz der römischen Epigraphik: litterae aureae," pp. 117-138). Based on an analysis of the content, character and location of the inscriptions, Alföldy also demonstrated that it was solely at the ruler's behest that inscribed monuments honouring representatives of the senatorial estate and high state dignitaries could be located in the public space, and only in designated areas of the city ("Statuen, Inschriften und die Gesellschaft in Rom und im Imperium Romanum," pp. 139-152; "Pietas immobilis erga principem und ihr Lohn: Öffentliche Ehrenmonumente von Senatoren in Rom während der Frühen und Hohen Kaiserzeit," pp. 153-186; "Örtliche Schwerpunkte der medialen Repräsentation römischer Senatoren: Heimatliche Verwurzelung, Domizil in Rom, Verflechtungen im Reich," pp. 187-203; “Inschriften und Biographie in der römischen Welt," pp. 205-225). He also highlighted the politically and socially important phenomenon of using inscriptions to exhibit the role of the senatorial aristocracy, which appeared in the period of the Late Empire, when Rome lost its significance as a capital ("Difficillima tempora: Urban Life, Inscriptions and Mentality in Late Antique Rome,” pp. 229-242).

The rulers interfered in the public space to a lesser extent in the provinces. Although the representatives of local social elites had greater opportunities to publicly exhibit their position and merits in these regions, the status of the emperor and his official representatives was also reflected there. Epigraphical evidence from the provinces shows that even there, a strong influence of imperial propaganda could be observed. Alföldy was able to make such claims on the basis of years of study of inscriptions from Spain ("Römische Inschriftenkultur von Hispanien bis zum Vorderen Orient: Die Erfolgsgeschichte eines antiken Kommunikationsmediums," pp. 35-51; "Tausend Jahre epigraphische Kultur im römischen Hispanien: Inschriften, Selbstdarstellung und Sozialordnung," pp. 243-277; “Text, Schrift, Monument und Raum. Epigraphik und Archäologie im römischen Hispanien," pp. 279-298; "Die Entstehung der epigraphischen Kultur der Römer an der Levanteküste," pp. 299-315), especially Tarragona ("Die frühe epigraphische Kultur von Tarraco: Von den Anfängen bis zur höchsten Blüte,” pp. 317-339; "Officina lapidaria Tarraconensis," pp. 341-363; see also below). This is also confirmed by data from other regions of the empire ("Römische Inschriftenkultur in Südwestdeutschland," pp. 365-373; "Die Anfänge der epigraphischen Kultur der Römer an der Donaugrenze im 1. Jahrhundert n. Chr.," pp. 375-390).

The seven articles in the second part of the book ("Vergangenheit, Gegenwart und Zukunft der epigraphischen Forschung," pp. 391-537) are somewhat different. Three lengthy texts provide biographies of scholars: Theodor Mommsen, Hans-Georg Pflaum, Eric Birley, Herbert Nesselhauf, Harold von Petrikovits and Ronald Syme. In Mommsen's case, the author's objective was to describe this scholar's services in producing the Corpus Inscriptionum Latinarum and the impact of this work on the development of epigraphical studies ("Theodor Mommsen und die römische Epigraphik aus der Sicht hundert Jahre nach seinem Tod," pp. 393-415). For the other scholars, Alföldy offers his very personal recollections. Some of them were his academic masters, and 
others colleagues with whom he became good friends over the decades ("Vier große Epigraphiker des 20. Jahrhunderts: Hans-Georg Pflaum, Eric Birley, Herbert Nesselhauf und Harald von Petrikovits," pp. 417-446). The words he dedicates to them go beyond the incidental reminiscences contained in obituaries. They are full of personal remarks and reflections, which often cast a great deal of light on the academic output of each, and also show what a significant impact they had on the author's personal fortunes and academic career. Particularly notable is the extensive essay on Ronald Syme, the various parts of which were written over the course of 20 years ("A Garden of Delights. Ronald Syme: Literature, Epigraphy, Prosopography and History,” pp. 447-482). It contains an insightful analysis of the great English historian's research methods, providing something of a key to understanding his work.

The four remaining texts in the second part of the book concern the role and importance of epigraphy in historical research, methodology of epigraphical studies, evaluation of the current state of such studies and reflection on their further development. These are one-off pieces, featuring the content of Alföldy's papers given at international epigraphical congresses in Rome ("Die Zukunft der Epigraphik," pp. 483-498) and Barcelona ("Forschungen zu antiken Inschriften 1997-2002," pp. 499-513), a ceremony at which he was awarded the title of doctor honoris causa by the University of Lyon ("L'Edition des corpora des inscriptions romaines," pp. 515-519), and a conference in Berlin ("Die Inschriften von Tarraco im Corpus Inscriptionum Latinarum: Geschichte, Probleme und Perspektiven einer epigraphischen Edition," pp. 521-537). Each of these texts is slightly different from the original. Since they were published a number of years earlier, the editors of the new edition either expanded them a little or supplemented them with recent bibliographical data. Despite their singular nature, none of them has lost its value or relevance.

There is no doubt that the latest collection of Géza Alföldy's articles will find a place on the desk of every researcher of the history of the Roman Empire. It is particularly important because its observations provide an understanding of the methods and insight into the tools and rules of the propaganda exercised by the Roman emperors in both the capital of the empire and the provinces, as well as demonstrating how important and useful a method epigraphy is for increasing our knowledge on Roman society, especially at the higher levels. The two editors of the volume deserve gratitude for making these texts available. Although the author himself prepared a large part of it for print before his death, it is only thanks to their efforts and enormous investment of work, whose effects are visible in the editing of each text, that it saw the light of day.

Edward Dąbrowa 